\title{
Regional Disparity Level at West Papua Province
} Qoni Santoso Nugraha ${ }^{1}$, Agus Dwi Wicaksono ${ }^{2}$, Nyoman Suluh Wijaya ${ }^{3}$

\author{
${ }^{1}$ Master Programme of Urban and Regional Planning, Brawijaya University, Malang, Indonesia \\ ${ }^{2,3}$ Urban and Regional Planning, Faculty of Technic, Brawijaya University, Malang, Indonesia
}

\begin{abstract}
A region possesses different potentials, conditions, and characteristics. Those aspects generate disparities between regions. Several factors that causing regional disparities related to physical and economic variables. Based on Gross Domestic Regional Product (PDRB) of West Papua Province 2012-2016, there were several sectors that significantly raised, i.e. mining and excavation, processing industry, and construction. Sorong City and Manokwari District had a domination role to the surrounding areas, and it affected into the imbalance growth speed of each areas, which in turn, it triggered the regional disparities. Manokwari is a capital of West Papua Province and a central of governmental activities, so the district got a fairly complete facilities, such as health, education, transportation, etc. The same condition was also applied to Sorong City. Therefore, the research objectives was to identify the regional disparity level reviewed from the population, facilities and infrastructures, and regional economic based on Gini Index and Williamson Index. The results showed that the regional disparities on the scale of a province were medium level. On District scale, the results showed Pegunungan Arfak District was included in high level of disparity. Whereas the low level of disparity was concluded on Fakfak District, Kaimana District, Teluk Wondama District, Teluk Bintuni District, Manokwari Selatan District, Sorong District, and Raja Ampat District.
\end{abstract}

Keywords — West Papua Province, disparity level, regional.

\section{INTRODUCTION}

West Papua Province is consisting of twelve districts. Based on Gross Domestic Regional Product (PDRB) of West Papua Province 2012-2016, there were several sectors that significantly developed, i.e. mining and excavation, processing industry, and construction. Those sectors were closely related to the effort of West Papua Province to develop the infrastructure on land, air, and sea at the last five years. The increased accessibility of areas has the role to stimulate the development level of an area. Level of social services could be reviewed from education sector; the distributions of colleges were concentrated at Sorong City, Manokwari District, Fakfak District, and Teluk Bintuni District. The comprehensiveness of educational facilities was linier with the development of human resources. Facilities and infrastructures aspects that made Sorong City and Manokwari District had a domination role to the surrounding areas, and it affected into the imbalance growth speed of each areas, which in turn, it triggered the regional disparities. The research objectives was to identify the regional disparity level reviewed from the population,, facilities and infrastructures, and regional economic based on Gini Index and Williamson Index.

\section{METHODS}

\subsection{Research Variables}

The research variables were formulated from theoretical review related to area's characteristic and disparities, also by reviewing previous research with similar themes.

\subsection{Research Methods}

Evaluative analysis method was used to discover the disparity level of a region in West Papua. The analysis was done using Gini index and Williamson index techniques.

\subsubsection{Gini Index}

Gini Index is a brief index about the inequality of income distribution's level in a country. It can be obtained by counting the area of a region or diagonal line (perfect equality) with Lorenz curve compared to the half area of where the Lorenz curve is located. [7] 


\section{TABLE 1}

\section{RESEARCH VARIABLES}

\begin{tabular}{|c|c|c|}
\hline References & Variables & Data types \\
\hline $\begin{array}{l}\text { There are factors that could cause regional } \\
\text { disparities, which are related to physical and social } \\
\text { economic variables. [1] }\end{array}$ & $\begin{array}{l}\text { - physical } \\
\text { • social } \\
\text { • economy }\end{array}$ & $\begin{array}{l}\text { - physical } \\
\text { • social } \\
\text { • economy }\end{array}$ \\
\hline $\begin{array}{l}\text { The development level of a region is essentially a } \\
\text { function from natural environment, population, } \\
\text { economic and social activities, that in turn will affect } \\
\text { the development level of the region.[2] }\end{array}$ & $\begin{array}{l}\text { - the development level of the } \\
\text { region }\end{array}$ & $\begin{array}{l}\text { - population } \\
\text { - economy } \\
\text { - social }\end{array}$ \\
\hline $\begin{array}{l}\text { The components of region's development consist of } \\
\text { [3]: } \\
\text { - The amount of economic and social facilities: } \\
\text { educational facility, health facility, worship } \\
\text { facility, and economical facility. } \\
\text { - Population: The amount of the population and the } \\
\text { density of the population. } \\
\text { - Region's Accessibility: The width of the region, } \\
\text { the distance to the district and the length of the } \\
\text { road. }\end{array}$ & $\begin{array}{l}\text { - Social Facility } \\
\text { - Population } \\
\text { - Accessibility }\end{array}$ & $\begin{array}{l}\text { Social Facility } \\
\text { - Educational facility } \\
\text { - Health Facility } \\
\text { - Worship facility } \\
\text { Population } \\
\text { - The amount of the population } \\
\text { - The density of the population. } \\
\text { Accessibility } \\
\text { - The width of the region. } \\
\text { - The distance to the capital. } \\
\text { - The length of the road. }\end{array}$ \\
\hline $\begin{array}{l}\text { The public facility and infrastructure is a facility that } \\
\text { is needed by many people and the provision is done } \\
\text { simultaneously. } \\
\text { The level of fulfillment was used to measure the } \\
\text { level of disparity of a region. } \\
\text { The public infrastructure consist of public facilities } \\
\text { such as the road, the bridge, the sewerage system, the } \\
\text { clean water supply system, the airport and the public } \\
\text { buildings. [4] }\end{array}$ & -Water Supply & -Water Supply Service User. \\
\hline $\begin{array}{l}\text { According to Urban Planning Dirjen Cipta Karya's } \\
\text { Dictionary, "The components of a region's } \\
\text { infrastructure are divided into } 3 \text { groups; } \\
\text { transportation infrastructure, health infrastructure } \\
\text { and energy and communication infrastructure. }\end{array}$ & - Energy Infrastructure & $\begin{array}{l}\text { - The level of electricity's } \\
\text { service. }\end{array}$ \\
\hline $\begin{array}{l}\text { According to Williamson (1940s), some critics } \\
\text { toward the stability and balance concepts can cause } \\
\text { the occurrence of the income's disparity concept } \\
\text { between regions. There are two important variables; } \\
\text { the amount of the population and the Gross Domestic } \\
\text { Regional Product (PDRB). [5] }\end{array}$ & $\begin{array}{l}\text { - The amount of the population. } \\
\text { - PDRB }\end{array}$ & $\begin{array}{l}\text { - The amount of the population } \\
\text { - PDRB's score in the last } 5 \\
\text { years. }\end{array}$ \\
\hline $\begin{array}{l}\text { The measurement of the income's imbalance level of } \\
\text { a country was obtained by counting the sector's ratio } \\
\text { which located in between the diagonal line and } \\
\text { Lorenz curve divided by the half area of where the } \\
\text { Lorenz curve is located. This ratio is also known as } \\
\text { Gini Concentration Ratio or Gini Coefficient. [6] }\end{array}$ & - Income/ outcome & - Outcome \\
\hline
\end{tabular}

In the Figure 1, Gini coefficient is shown in the comparison of region A (the area with perfect equality line and Lorenz curve) with triangle BCD. The name of Gini coefficient is taken from statistic expert named C. Gini. He was the first person who found the formula in 1912. 


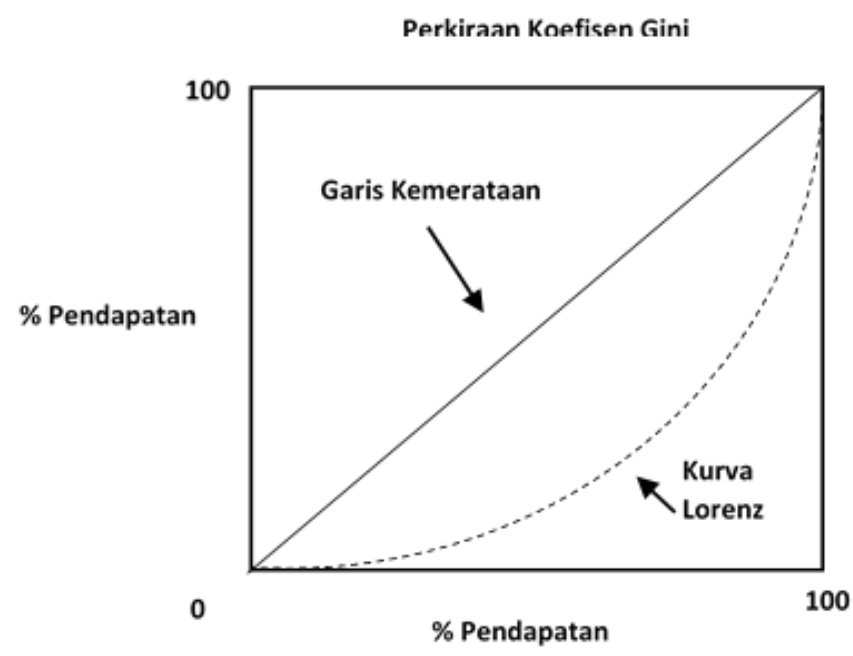

\section{FIGURE 1. GINI COEFFICIENT ESTIMATION}

MS. Excel was used to calculate Gini coefficient, with the following steps:

\section{Input data}

Input data are population (amount and density), sosial facility (education, health and religious) and accessibility (the area, the distance to the capital, and the length of the road) and mean outcome per capita (Rp/kpita/month) based on the group of the outcome per capita a month.

\section{Calculation Process}

Step 1. Calculate the cumulative proportion of population $(\mathrm{Xk})$ with formula, add $\%$ the lowest cumulative population with $\%$ the second lowest cumulative population, divided by the total population

Step 2. Calculate the cumulative income portion (Yk) with the formula \% the lowest cumulative income plus total income divided by total income.

Step 3. Calculate $\mathrm{Xk}-\mathrm{Xk}-1$ (\% Cumulative population)

Step 4. Calculate Yk + Yk -1 (\% Cumulative income)

Step 5. Calculate $(\mathrm{Xk}-\mathrm{Xk}-1)(\mathrm{Yk}+\mathrm{Yk}-1)$

Step 6. Calculate G1

\section{The Result}

Interpretation of the result of calculation with Gini coefficient:

\section{TABLE 2}

\section{COEFFICIENT VALUE OF GINI COEFFICIENT}

\begin{tabular}{|l|l|}
\hline Coefficient Value & Income's distribution \\
\hline $\mathbf{G I}=\mathbf{0}$ & Perfect equality \\
\hline $\mathbf{0}<\mathbf{x}<\mathbf{0 , 4}$ & Low inequality level \\
\hline $\mathbf{0 , 4}<\mathbf{x}<\mathbf{0 , 5}$ & Medium inequality level \\
\hline $\mathbf{0 , 5}<\mathbf{x}<\mathbf{1}$ & High inequality level \\
\hline \multirow{2}{*}{ GI $=\mathbf{1}$} & Inequality \\
\cline { 2 - 2 } & (controlled bye one person) \\
\hline
\end{tabular}

\subsubsection{Williamson Index}

Williamson index method was used to analyze how big the disparity was between regions in West Papua. Unlike the Gini Ratio that usually used to calculate the income distribution, Williamson index used the (PDRB) per capita as a fundamental data. The Williamson formula index is: 


$$
c v_{w}=\frac{\sqrt{\overline{\sum(\mathrm{Yi}-\bar{y})^{2} f i / \mathbf{n}}}}{\bar{y}}
$$

Explanation:

$\mathrm{CVw}=$ Williamson Index

$\mathrm{fi}=$ the amount of population in the district

$\mathrm{n}==$ The amount of West Papua's populatioon

Yi = PDRB per capita district/capital (Rupiah)

$\bar{y}=$ PDRB per capita mean West Papua (Rupiah)

\section{FINDING AND ARGUMENTS}

\subsection{Region's Characteristic}

The result of identification towards the region's characteristic showed several conditions such as:

\section{a. Social Facilities}

The largest numbers of educational facilities were located in Manokwari District with 346 units. Whereas, South Manokwari District has only 69 units. The largest numbers of health facilities were located in Manokwari District with 470 units. Whereas, Pegunungan Arfak District had the fewest health facilities with 41 units. The largest numbers of religious facilities were located in Manokwari District with 1.499 units. Whereas Pegunungan Arfak District had no religious facility.

\section{b. Accesibility}

West Papua's Total area is 9.967.163 Ha, Teluk Bintuni District has the largest area with 2.084.083 Ha or $21 \%$ of the total area of West Papua, Whereas the smallest area is Sorong City with $65.664 \mathrm{Ha}$ or 1\% of the total area of West Papua. The longest distance between cities are Kaimana-Manokwari, whereas the shortest distance between cities are RansikiManokwati. Based on the road's pavement, the road in West Papua could be consist of one of these: asphald, gravel, soil, etc. In 2012, the lenght of the road with asphald was $1.817 .824 \mathrm{~m}$, while in 2016 , it got longer to $2.467 .949 \mathrm{~m}$. There was a significant enhancement of the road with asphald from 2012 to 2016, spesifically $650.126 \mathrm{~m}$.

\section{c. Infrastructure}

The use of electricity especially State Electricity Company (PLN) haven't reach to some regions yet. The regions that havent got to use the State Electricity Company are: South Sorong District, Sorong District, Tambrauw District, Maybrat District, South Manokwari District and Pegunungan Arfak District. The telecommunication's network in West Papua was evolving rapidly through telephone provider that developed the network at least in the capital of every district/city. The amount of water supply service user in districts of West Papua in 2012 was 42.202 user, and in 2016, it was increased to 64.957 user.

\section{d. Populations}

The populations in West Papua was in total 194.050 individuals. Sorong City was the most populous city in West Papua with 225.588 individuals. Whereas, on 2016, the least populous city/district was Tambrauw District with 13.615 individuals.

\section{e. Outcome}

In 2012-2016, Sorong City had the largest outcome per capita in West Papua with Rp.1.448.834,00. Whereas, Tambrauw District had the smallest outcome per capita with Rp.381.247,00.

\section{f. Gross Domestic Regional Product (PDRB)}

The highest PDRB Based on Constant Price according to field of works in West Papua was Teluk Bintuni District with Rp.22.738.912,98, whereas the lowest PDRB was Pegunungan Arfak District with Rp.112.343,7.

\subsection{Region's Disparity Level}

The disparity level of regions in West Papua can be determined by some aspects, i.e: Physic, Social and economic using analysis method Williamson index and Gini index. 


\subsubsection{Williamson Index}

The analysis result of disparity in districts/cities of West Papua according to Williamson index was divided in 3 category; district/city with low disparity level (Williamson index's score is $<0.3$ ), district/city with medium disparity level (Williamson index's score is $0.3-0.7$ ) and district/city with high disparity level (Williamson index's score is $>0.7$ ).

TABLE 3

Williamson INDEX ANALYSis IN WeSt PAPUA

\begin{tabular}{|c|c|c|c|c|c|c|}
\hline \multirow{2}{*}{ No. } & \multirow{2}{*}{ District/City } & \multicolumn{5}{|c|}{ PDRB per capita } \\
\cline { 3 - 6 } & & $\mathbf{2 0 1 2}$ & $\mathbf{2 0 1 3}$ & $\mathbf{2 0 1 4}$ & $\mathbf{2 0 1 5}$ & $\mathbf{2 0 1 6}$ \\
\hline 1 & Fakfak District & 0,29 & 0,28 & 0,18 & 0,17 & 0,15 \\
\hline 2 & Kaimana District & 0,06 & 0,04 & 0,23 & 0,23 & 0,24 \\
\hline 3 & Teluk Wondama District & 0,26 & 0,26 & 0,20 & 0,19 & 0,19 \\
\hline 4 & Teluk Bintuni District & 0,24 & 0,24 & 0,23 & 0,22 & 0,22 \\
\hline 5 & Manokwari District & 0,84 & 0,80 & 0,35 & 0,32 & 0,30 \\
\hline 6 & South Manokwari District & - & - & 0,59 & 0,89 & 0,52 \\
\hline 7 & Pegunungan Arfak District & - & - & 0,43 & 0,78 & 0,77 \\
\hline 8 & South Sorong District & 0,58 & 0,55 & 0,34 & 0,33 & 0,32 \\
\hline 9 & Sorong District & 0,08 & 0,08 & 0,21 & 0,20 & 0,20 \\
\hline 10 & Raja Ampat District & 0,02 & 0,01 & 0,05 & 0,04 & 0,05 \\
\hline 11 & Tambrauw District & 0,89 & 0,94 & 0,70 & 0,67 & 0,64 \\
\hline 12 & Maybrat District & 0,55 & 1,03 & 1,02 & 1,02 & 1,01 \\
\hline 13 & Sorong City & 0,55 & 0,48 & 0,34 & 0,30 & 0,27 \\
\hline TOTAL & West Papua & 0,40 & 0,43 & 0,44 & 0,49 & 0,44 \\
\hline
\end{tabular}

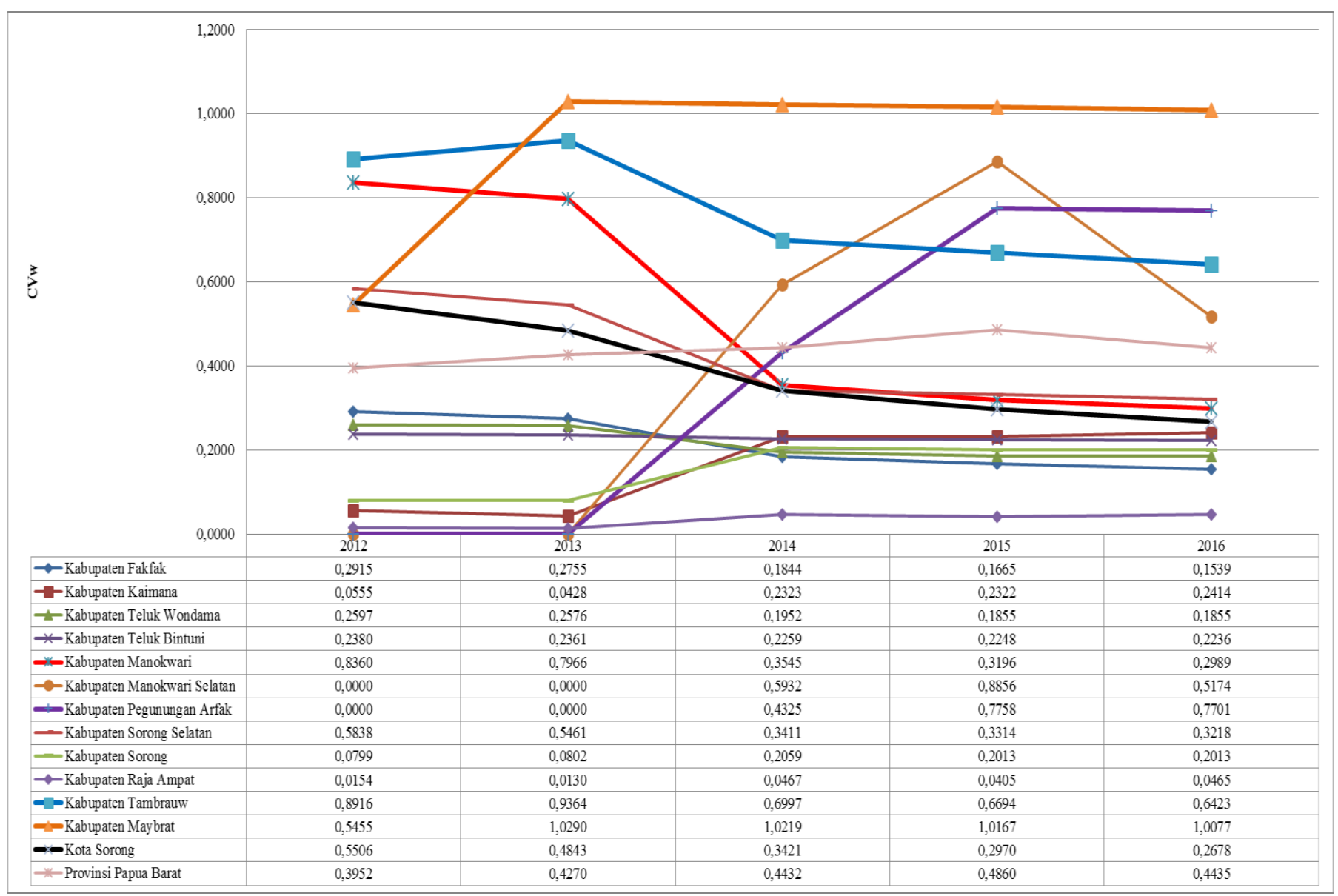

FIGURE 2: CVW FROM PDRB PER CAPITA OF CITIES/DISTRICTS IN WEST PAPUA AT 2012-2016 
In 2012-2016, the results of Williamson index for the disparity of construction's scale of West Papua showed that West Papua's level was medium and the mean was 0.4. Whereas, the disparity of construction between districts/cities in West Papua (table 1) showed that the highest construction's disparity level Were Pegunungan Arfak District and Maybrat District which mean that the construction in those regions weren't equal. The districts with medium disparity level were Manokwari District, South Manokwari District, Tambraw District and South Sorong District. Whereas, the lowest construction's disparity level was Fakfak District, Kaimana District,Teluk Wondama District, Teluk Bintuni District and Sorong District which mean that the construction in those districts/cities were equal. The conclusion is, in 2012-2016, the development of disparities between cities/districts decreased.

\subsubsection{Gini Index}

The analysis results of the disparity in districts/cities of West Papua according to the population,outcome, social facilities and physic variables can be seen on table 2 and figure 2 .

\section{TABLE 4}

Gini IndeX ANALYSis IN WEST PAPUA

\begin{tabular}{|c|c|c|}
\hline Variable & $\mathbf{2 0 1 2}$ & $\mathbf{2 0 1 6}$ \\
\hline Population & 0,52 & 0,39 \\
\hline Outcome & 0,22 & 0,26 \\
\hline Educational & 0,32 & 0,26 \\
\hline Health & 0,26 & 0,29 \\
\hline Religious & 0,47 & 0,48 \\
\hline Electricity & 0,49 & 0,43 \\
\hline Water supply & 0,76 & 0,47 \\
\hline Accessibility & 0,52 & 0,43 \\
\hline
\end{tabular}

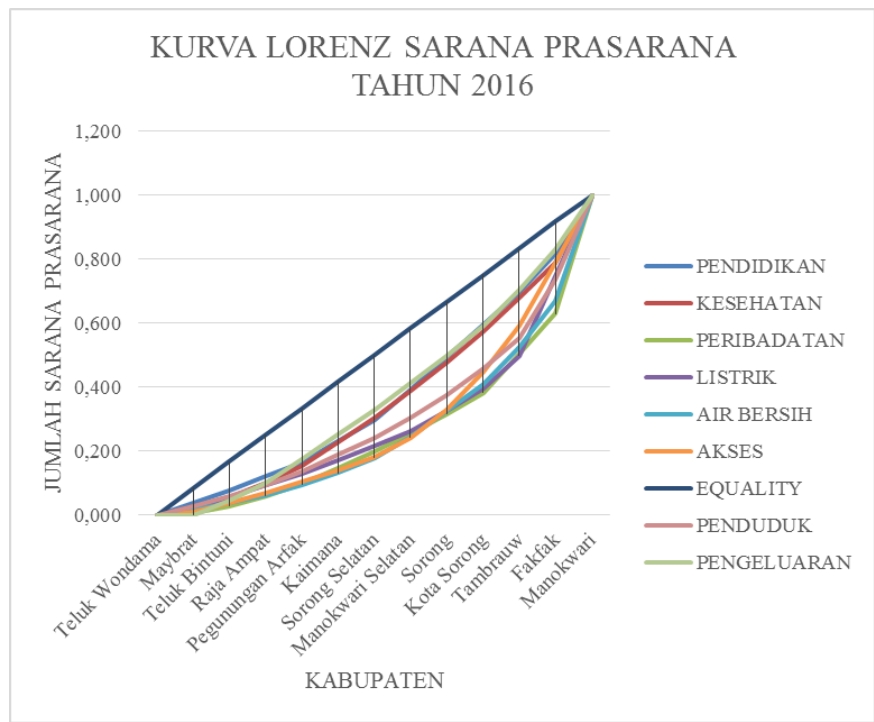

Figure 2 LORENZ CURVE

\section{CONCLUSION AND RECOMMENDATION}

\subsection{Summary}

The reseach's conclusion were described as below:

a. The disparity level of West Papua in 2012-2016 was decreased. It showed that West Papua was putting an effort to make a construction's equity in every regions. The results showed that the regional disparities on the scale of a province was medium level. 
b. On District scale, the results showed Pegunungan Arfak District was included in high level of disparity. Whereas the low level of disparity was concluded on Fakfak District, Kaimana District, Teluk Wondama District, Teluk Bintuni District, Manokwari Selatan District, Sorong District, and Raja Ampat District.

c. As per sectors, the disparity level of West Papua were concluded, i.e.:

- On 2012-2016, the disparity level of outcome per capita in West Papua was low. It means that the distribution of the outcome per capita was equal.

- The disparity level of population's distribution decreased, it means that the population's distribution of West Papua started to be equal.

- The disparity level of educational and health facilities was low. It means that the distribution level of educational and health facilities was equal. Whereas, the disparity level of religious facilities is medium. It means that the level of distribution of religious facilities was not equal yet.

- On 2012-2016, the disparity level of electricity infrastructure was medium. It means that the distribution's level of electricity infrastructure was equal but did not increase. Whereas, the disparity level of water supply service and accesibility decreased from the high level to medium level. It means that the distribution of water supply service and accesibility was equal and increased.

\subsection{Recommendation}

Based on the research results, recommendation given to the West Papua Province Government, as the main stakeholders in the effort to lessen the disparities between districts/cities, is to push the equity of economic development, increase water supply services so that it could be distributed evenly thorough the regions, and increase the educational facilities. Also, recommendation for districts government to push the equity of area's development, especially addressed to the government of Pegunungan Arfak District and Maybrat District.

\section{REFERENCES}

[1] Rustiadi, Erman. DKK. 2009. Perencanaan dan Pengembangan Wilayah. Jakarta: Crestpen Press dan Yayasan Obor Indonesia.

[2] Budiharjo, E. 1995. Tata Ruang Pembangunan Daerah. Gajah Mada University Press, Yogyakarta.

[3] Rustiadi, Ernan, Dkk.(2011). "Perencanaan dan Pengembangan Wilayah”.Jakarta: Yayasan Pustaka Obor Rakyat.

[4] Sadyohutomo, Mulyono. 2009. Manajemen Kota dan Wilayah, Realita dan Tantanan. Penerbit Bumi Aksara. Jakarta.

[5] Adisasmita Raharjo, Teori-Teori Pembangunan Ekonomi (Pertumbuhan Ekonomi Dan Pertumbuhan Wilayah), Graha Ilmu, Yogyakarta, 2013.

[6] Munandar Haris, Pembangunan Ekonomi di Dunia Ketiga, Erlangga, Jakarta, 2000.

[7] Arsyad Lincolin, Ekonomi Pembangunan, Unit Penerbit dan Percetakan STIM YKPN Yogyakarta, 2010.

[8] Sjafrizal, 2008. Ekonomi Regional, Teori dan Aplikasi. Padang: Niaga Swadaya. 